\title{
ВКЛАД РУССКИХ УЧЁНЫХ МОНГОЛОВЕДОВ В РАЗВИТИИ КУЛЬТУРОЛОГИИ МОНГОЛИИ И ИЗУЧЕНИИ МОНГОЛЬСКОЙ КУЛЬТУРЫ
}

Реальное положение развития культурологии в Монголии состоит из двух частей. С одной стороны, исследования наших Монгольских учёных своей культуры, с другой исследования в культурологии Монголии зарубежных учёных монголоведов в области археологии, антропологии, этнографии, истории и филологии. Необходимо при это отметить весомый вклад Российского монголоведения. Это во-первых, подготовка квалифицированных кадров в ВУЗ-х, во вторых, создание научных институтов для изучения истории и культуры Монголии. Эти два основных направления, в начале имевшие общественно политические цели постепенно преобразовались и сформировались в научное положение. Впервые в 1833 году в Казанском университете была создана кафедра монгольской и калмыцкой словесности под руководством известного ученого монголоведа О. М. Ковалевского \1878-1901\. Так начиналась работа по подготовке монголоведов в России. В 1855 году в Санкт-Петербургском Государственном Университете создали факультет Востоковедения и кафедру калмыцкого и маньчжурского языков. Далее в университетах Москвы, Иркутска, Улан-Удэ готовились монголоведы разных поколений. Это они определили содержание обучения монгольской истории, культуры и смысл исследовательской работы. Историю равития Российского монголоведения можно разделить на 5 основных периода:

I. XVIII -начало XIX в

II. Период экспедиции Н.М.Пржевальского и его учеников

III. Период конца XIX в - первая половина XX в (Б. С. Задаев. 2006. С. 11. )

IV. Современный период \с 1960-1990 г г

V. Глобализационный период /с 1990 года /

Начиная с экспедиции под руководством таких учёных как Н. М. Преживальского (первая 1870-1873, вторая экспедиция 1876-1879, третая экспедиция 1879., четвёртая экспедиция 1883 , А. М. Позднеева (1880), Г. Н. Потанина (1883), П. К. Козлова (1923) А. П. Окладникова (1960) и монголоведы многих поколений успешно проводили исследования кочевников и монголов были немало проведены научные исследования по историческим материалом о создании и развитии оседлой культуры и цивилизации. Например В.В.Волков отметил во своем исследовании культуры и памятников монголов, что оседлая культура и цивилизация и традиция земледелия начались со конца неолита и начала бронзового века на территории Монголии. Такие культурные памятники как зернотерок, пестов для приготовления медицины и керамические изделия употребленных древными людьми свидетельствуют вышеупомянутые факты . Исторические памятники производства каменных орудий во время неолита найдены в Баянзаге Южногобийского аймака и в районе Чойбалсан и Тамсагбулаг . Х век оставил следы земледелия с высоким развитием и оседлой цивилизации в монгольской культуре и цивилизации. Таким образом 
русские учёные успешно проводили широкие исследование следа развития монгольской культуры.

Сотрудничество Комитета наук МНР с Монгольской комиссией Академии наук СССР оказал большую помощь в новом развитии исследовании культуры в Монголии. Главное направление этой совместной комиссии заключилось в том, что комиссия проводит научные исследования по монгольским природным ресурсам и их экономической возможности, а также культурное и гуманитарное исследование. Один из основателей монгольского исследования в России Б.Я.Владимирцов руководил это исследование и они могли собирать богатые материалы наследства монгольского языка, литературы и этнографии и фольклора.

После отечественной войны интерес иностранных учёных и исследователей увеличился и международные конференции и симпозиумы и совместные экспедиции свидетельствуют его. Как правило нам надо упомянуть Русско-Монгольская археологическоэтнографическая экспедиция под руководством С.В.Киселева, которая работала в Монголии в 1948-1949 годах .

И.Н.Устюжанинов (1952 году), Ф. С. Цаплина (1961 году), К. В. Вяткина (1964 году) проводили исследования по культурному строительству и культуре Западной Монголии сравнивая их с Бурятской и Алтайской культурой. Монография “Культурное стройтельство в МНР” написанное Г. И. Михайловым выпущена в 1957 году .

В истории МНР опубликованная 1954,1967 годах и в трудах по монгольской истории исследователей И. Я. Златкина, В. А. Масленникова , В. И. Писарева , Л. М. Гатауллиной коснулось конкретного вопроса о культурной революции. Общественность хорошо знает, что Русско-Монгольская археологическая экспедиция под руководством А.П. Окладникова внесла свой большой вклад в исследовании по древней Монгольской истории и культуре. В это время Русские этнографы и исследователи культуры и искусства в том числе Х. Ц. Ральдин (1963, 1965 гг), В. П. Дарбакова (1966-1967 гг), Н. В. Кочешков (1964, 1966 гг), Л. Л. Викторова (1967, 1968 гг) вместе с монгольскими учёными и исследователями проводили совместные экспедиции . В результате этих археологических и этнографических экспедиции расширилась сфера многолетного понятия “Монголлика” в кругах классической филологии .

Один из больших результатов Русско-Монгольского научного сотрудничества по исследованию культуры был “Совестко-Монголькой комплексной историко-культурной экспедиции” начатой с 1969 года. Эта экспедиция состоял пятых отрядов и три из них были археологическими экспедициями по исследованиям историко-культурных памятников палеолитного и неолитного, бронзового и железного периодов и городов средневековой Монголии. Остальные были исследованием эпиграфии (петроглиф) и этнографии. Свыше 30 археологов, историков, этнографов и учёных по языку и литературе и смогли собирать значительные находки и материалы в результате их полевых исследований за 1969, 1970, 1971 годы. В особенности исследование по палеолитному периодам не только обеспечило возможность для периода но и находки связанные с низким палеолитом, найденные в Даригангийском районе Сүхэ-Баторского аймака имеет значение в движении исторической летописи вперёд много тысяч лет 
оседания монголов в этом месте. А также обнаружились петроглифы Ямаан-усан, которые показали многие стороны жизни древных монгольских племён в за Алтайском гоби. Историко-культурный памятник с древной тюркской надписью, найденный по этому исследованию в устьи реки Тэхийн гол считается одним из самых больших памятников тюркского периода в Монголии .

150 оленных памятников, Бугатская Согдийская (YI зуун), библеотека из Хар бухын балгаса, связанная с XYII веком, которая много привлекала внимание историков и культурологов, были найдены в рамках экспедиции. Отряд этнорафического исследования, охвативший 8 аймаков и проходивший маршрут 15 тысяч километров проводил исследования по этнических культурных особенности халхасцов, баргутов, хотгойдцов, элжгинцов, баятов, дербетов, хотонов, мянгатов, дзахчинов торгутов. Исследования русских этнографов учёных был работой широкой сферы, охватывшая проблемы этнического и культурного происхождения монголов до Чингисовского периода, верование до распространения жёлтой религии в Монголию и влияние распространения жёлтой религии, современное верование в Монголии, изменение традиционной культуры монгольских кочевников и взаимодействие культуры современного человечества и монгольской культуры.

Институт этнографии им. Н. Н. Миклухо-Маклая РАН постоянно проводил широкие научно-исследовательские работы по истории и происхождению монгольской традиционной культуры и опубликовали многие книги труды. Мы можем называть такие труды как В. Л. Егоров “Жилище населения Монгольской Народной Республики. Типы традиционного сельского жилища народов Юго-Восточной, Восточной и Центральной Азии” (1979)., Л. Л. Викторова "МОНГОЛЫ: Происхождение народа и истоки культуры" (1980), “Монгольская одежда. -“Сборник МАЭ”(1977, №32)., Н. Л. Жуковская “Ламаизм и ранние формы религии” (1977), “Категории и символика традиционной культуры монголов” (1988), “Судьба кочевой культуры” (1990)., Н. В. Кочешков “Народное искусство монголов” (1973), “Проблемы историко-культурных связей монголоязычных народов” (на примере народного декоративного искусства XIX в. - середины XX в) //Этнические и историко-культурные связи монгольских народов (1983. С. 3-176) и научно-исследовательские труды других учёных и исследователей.

Учёный монголовед Н. Л. Жуковская отметил в своей статье “Монголия не была страной между двумя великими державами Россия и Китай, отделяясь от внешнего мира. Она конечно, училась от своих великих соседов и была открытим другой культуре в результате активных отношений Западных и Восточных народов. Но она является одной из немногих стран, которые могли сохранять классическую модель кочевой кульутры со своим специфическим характером . Н. Л. Жуковская исследовала вопрос о взаимоотношении между традиционной верой и жёлтой религией монгольского и бурятского народов на основе материалов экспедиции проведённой в Монголии и Сибирии и исторических и архивных материалов связанных с шаманизмом. Она называла религию гэлукпа (в Тибете жёлтая религия называется гэлукпа и в Монголии называется жёлтая религия) которая основана Зонховым в Тибете ламаизм в широком, как европейцы назвали желтую религию. Автор написал об использовании ламаизма в широком смысле, охватывая древные направления этой религии махаяна и важраяна, которые вместе с гэлукпа 
распространились в Монголии . Этот труд отметил как древные веры монголов выразились в обычаях шаманизма и жёлтые религии на основе богатых материалов, связанных с историей буддийской религии.

Л.Л.Викторова рассмотрела исторические условия происхождения и формирования древных монгольских племён и происхождение и истоки основных монгольской традиционной культуры во своем научном труде “МОНГОЛЫ: Происхождение народа и истоки культуры” (1980). Этот труд является первым комплексным исследованием, которое рассмотрело отношении и связи монгольских племён XIII века и особенность происхождения и времени развития и пространства образа коренной монгольской жизни и культуры с точки зрения истории, этнографии и этнокультурологии.

Мы должны почеркнуть, что научные статьи, очерки, книги и труды И. М. Майского , Э. А. Новоградовой внесли свой большой вклад в исследовании по монгольской культуре.

В научном труде “Очерки истории культуры МНР” (1971) выпущееном Сибирским отделением Академии наук России, Бурятским отделением и Институтом общественных наук в честь 50 летия Монгольской народной революции классифицировалась на две части: “Культурное строительство на демократическом этапе революции в 1921-1940 годах" и “Культурная революция МНР в 1940-1967 годах" и были проведены исследования с точки зрения марксистской и ленинской теории культуры . Это отличается первым комплексным трудом, который исследовал строительство социалистической культуры, что заново появилась и развивалась за годы после народной революции в её системе. Бурятско-Монгольская команда в составе Р. Е. Пубаев, Д. Б. Улымжиев, Р. Л. Балдаев, Г. Н. Заятуев, С. Пүрэвжав, Б. Д. Цибиков, Л. К. Герасимович, В. Ц. Найдаков, Б. Ф. Смирнов, И. И. Соктоев, Г. Г. Банчикова, Г. Л. Санжиев, Т. Содномдаржаа, Б. Дашцэвэг, Г. Эрдэмбилиг, Ш. Магван проводил исследования исторических материалов о создании и развитии культурно-просветительных учреждений с целью просвещения народа в Монголии в широкой сфере образования, культуры, науки, искусства, литературы, печати, информации, здоровохранения, спорта, материального состояния, традиции и обычая с помощью Академии наук Монголии и Бурятского отделения Акакдемии наук России .

В труде этой команды рассмотрелись первый демократический этап (1921-1940) на три периода. Например, первый период (1921-1924гг)-подготовительный период для обеспечения общественно-политических условый, второй период (1925-1932гг)- борьба за развитие демократической революционной культуры, третий период (1932-1940гг)конечный период демократического этапа культурной революции .

1940-1967 годы были переходным периодом монголов в социалистическое строительство. Х. Чойбалсан объяснил о значение обмен старого монгольского письма новым кирилльским письмом на Х съезде МНРП со всех сторон и совместное заседание ЦК МНРП и Совета министров МНР решили вопрос о применении нового письма (на основе русской графики и арабских цифров) . В постановлении совместного заседания подробно изучалась основа культурной политики, что "наша культура будет развиваться путём укрепления дружественных отношений и изучения богатой традиции русской культуры” со всех сторон. Исследования культурного строительства на основе его классификации и 
на периоды 1940-1945 годы, 1945-1952 годы и новое время завершения строительства социализма в МНР и вывод сделанный на них в труде комплексного исследования очень ценны. Кроме того многие учёные как А. Сарипсов , В. А. Рязановский , Б. Такмаков , В. А. Сергеев , К. Л. Малакшанов , Л. Роглан , Е. И. Лиштованный , Ш. Б. Чимитдоржиев , Е. М. Даревская проводили исследования в рамках новой Монгольской культурной политики.

Е. М. Даревская в труде “Сибирь и Монголия. Очерки русско-монгольских связей в конце IX - начале XX веков” широко рассмотрела вопрос о Русско-монгольских политических, экономических и культурных отношениях. Она изучила деятельности культурнопросветительных организаций как русские школы, библиотеки, издательства, клубы, кино театры и первой отравке студентов в Сибирию на основе интересных исторических и архивных материалов. Её исследования по ознакомлению монголов с современной культурой путём организации лекций, концертов, встреч и вечеров в русском клубе и по распространению новой кульутры в Монголии привлекали внимание.

Последное время Бурятский научный центр Институт общественных наук Сибирского отделения Российской Академии наук в Улан-Үде стал один из крупным центром Российского Монголоведения. Основная нагрузка Монголоведческого исследования лежит на плечах таких учёных, как Ш.Б.Чимитдоржиев, А.Д.Улымжиев, Т.Д.Скрынникова, Б.З.Базаров, С.П.Ванчикова, Д.С.Дугаров, Б.С.Дугаров и другие.

Активные всесторонные исследования русских учёных монголоведов в Казане, СанктПетербурге, Москвы, Иркутске и Улан-Үдэ о монгольской культуре имел заслугу для обеспечения почвы научно-исследовательской работы для самостоятельного развития культурологии в нашей стране.

* Ж. Долгорсурэн - МУСУИС-ийн багш, доктор, профессор

Пржевальский Н. М. Монголия и страна тангутов. -М, 1946.

Позднеев А. М. Города Северной Монголии. СПб, 1880, Позднеев А.М. Монголия и монголы. Результат поездки в Монголию, исполненной в 1892-1893 гг. Т. 1. СПб, 1896.,

Потанин Г. Н. Очерки северо-Западной Монголии. -Вып, 4. Материалы этнографические. СПб, 1883.

Козлов П. К. Монголия и Амдо и мертвый город Хара-хото. -М,-Пб., 1923., П. К. Козлов "Монголия и Кам. Трехлетнее путешествие по Монголии и Тибету. (1899-1901 гг.).-М, 1947., П. К. Козлов. Дневники Монголо-Тибетской экспедиции. 1923-1926. /Отв.ред. А. В. Постников; Ред.-сост. Т. И. Юсупова; Сост. А. И. Андреев. СПб., 2003. Научное наследство. Т. 30.

Волков В. В. Бронзовый и ранний железный век Северной Монголии, Автореф. Канд. Дис., М., 1965, С. 21-22 
Ринчин Б. Д-р, проф. Из нашего културного наследия. Улун-Батор, 1958, С. 4.

Древнемонголькие города. -М, 1965., К. В. Вяткина. Монголы Монгольской Народной Республики // Восточно-Азиатский этнографический сборник, “Труды Ин-та этнографии АН СССР”, нов. Серия, Т. LX, М-Л., 1960.

Устюжанинов И. Н. Культура монгольского народа.-В сб.: <<МНР>>. М., 1952.

Цаплина Ф. С. Успехи культурного строительства.-В сб.: <<Монгольская народная Республика 1921-1961 гг >>, -М, 1961.

Вяткина К. В. Общие черты материальной и духовной культуры у западных монголов, бурят и южных алтайцев. М., 1964. (Международный конгресс антропологических и этнографических наук. М., август 1964).

Михайлов Г. И. Культурное строительство в МНР. Исторический очерк. М, 1957, Рец.: Г. К. Меклер.-//“Советское востоковедение”, 1958, №5. С. 189.

История Монгольской Народной Республики. М., 1954.

История Монгольской Народной Республики. М., 1967.

Златкин И. Я. Очерки новой и новейшей истории Монголии. М., 1957.

Масленников В. А. Монгольская Народная Республика на пупти к социализму. М., 1951.

Писарев В. И. МНР на пути к завершению строительства социализма. М., 1964.

Гатауллина Л. М. МНР в социалистическом содружестве. М., 1964.

Окладников А. П., Ларичев В. Е.. Археологические исследования в Монголии в 1967г., Известия Сибирского отделения (далее СО) АН ССР, 1968, №11, вып. 3, серия общественных наук; их же, Археологические исследования в Монголии в 1968 г., Известия СО АН СССР, 1969, №6, вып. 2, серия общественных наук; А. П. Окладников, А. П. Деревянко, Деревные культуры восточных районов в МНР, Сов. Археология, 1969\% №4; их же, Тамцак-Булак-неолетическая жультура Восточной Монголии, Труды Бурятского института общественных наук Бурятского филиала СО АН СССР, Улан-Удэ, 1970, вып. 13, серия востоковедения; В. Е. Ларичев, Азия далёкая и таинственная, Новосибирск, 1968 и другие работы.

Жуковская Н. Л. Этнографические исследования в МНР//Советская этнография. 1972.№5. С. 103.

Жуковская Н. Л. Этнографические исследования в МНР//Советская этнография. 1972.№5. C. 105.

Жуковская Н. Л. Этнографические исследования в МНР//Советская этнография. 1972.№5. C. 105. 
Кляшторный С. Г, Лившиц В. А. Согдийская надпись из Бугута, //Страны и народы Востока. Вып. Х, М., 1971

Жуковская Н. Л. Этнографические исследования в МНР. //Советская этнография. 1972. №5. C. 109.

Жуковская Н. Л. Ламаизм и ранние формы религии. М., 1977. С. 3.

Майский И. М. Монголия накануне революции. - М, 1959.

Э. А. Новоградова. Мифы и культы древней Монголии.-Вестник Академии наук СССР. 1980, № 2., Мир петроглифов Монголии.-М, 1984, И. Н.

Очерки истории культуры МНР. -Улан-Удэ, 1971.

Очерки истории культуры МНР. -Улан-Удэ, 1971. С. 13.

Монгол Ардын Хувьсгалт намын их, бага хурал. Төв хорооны бүгд хурлуудын тогтоол шийдвэр. II, 1940-1956, 25 дэх талд үз.

Очерки истории культуры МНР. -Улан-Удэ, 1971. С. 222. До 1941 г. В Монголии употреблялись тибетские цифры.

“Конституция и основные законодательные акты МНР”. М, 1952. С. 245-246

Мендэ, Сарипсов А. К проблеме культурной революции в МНР. // Хозяйство Монголии. 1930. №5 (23) - 6 (24), С. 55-64.

Рязановский В. А. К водросу о влиянии монгольской культуры и монгольского права на русскую культуру и право. Харбин, 1931. С. 31.//Отд. Оттиск из “Изв. Юридич. Фак.” Т. 9.

Такмаков Б. Культура и просвещение в Монголии. //Народное образование. 1949. № 11. С. 66-70., Б. Такмаков. Культура монгольских казахов. //Жулдыз. 1963, № 11, С. 135-140. (на казахском языке)

Сергеев В. А. Культурное строительство и рост материального благосостояния трудящихся Монгольской Народной Республики. //В кн.: “40 лет народной Монголии. М, 1961, C. 95-111.

Малакшанов К. Л. Советско-Монгольское культурное сотрудничество в период завершения строительства социализма в МНР // Труды Иркутского института народного хозяйства. Вып. 1. 1966. С. 203-220.

Роглан Л. Культурное строительство в Монгольской Народной Республике.//В кн.: Ответы на вопросы трудящихся. Сб. Вып. 62. М, 1966. С. 57-63.

Лиштованный Е. И. “Востоковедение в Иркутске”, //Сов. Молодёж. 1983. 2 июля. ., "Исторические взаимоотношения Сибирии и Монголии: культура и общество (XIX в. 30-е гг. ХХв)”. Улан-Удэ. Изд-во БНЦ СО РАН, 1998. С. 172 
Чимитдоржиев Ш.Б. Русско-Монгольские связи в области культуры и просвещения (нач. ХХ в) //Y международный конгресс монголоведов. Уланбатор, сент. 1987. Доклады советской делегации. -М., 1987. -Т. 1: История, экономика, - С. 170-179.

Даревская Е. М. Сибирь и Монголия. Очерки русско-монгольских связей в конце IX начале XX веков. Иркутск, 1994.

\section{Литературы:}

1. Археологические исследования в Монголии в 1968 г., Известия СО АН СССР, 1969, №6, вып. 2, серия общественных наук.

2. Балдо Б. Проблемы культурной революции при переходе к социализму в странах, не прошедших капиталистической стадии разтития. (На опыте культурной революции в МНР). Автореферат. Дисс. На соискание учён. Степени канд. Философ. Наук. М, Изд. ВПШ и АОН, 1959.

3. Викторова Л.Л. МОНГОЛЫ: Происхождение народа и истоки культуры. $-\mathrm{M}, 1980$, C. 181 .

4. Волков В. В. Бронзовый и ранний железный век Северной Монголии, Автореф. канд. дис., М., 1965, С. 21-22

5. Вяткина К. В. Общие черты материальной и духовной культуры у западных монголов, бурят и южных алтайцев. М., 1964. (Международный конгресс антропологических и этнографических наук. М., август 1964)

6. Гатауллина Л. М. МНР в социалистическом содружестве. М., 1964

7. $\quad$ Герасимович Л. К. Литература Монгольской Народной Республики (1921-1964 гг), Л., 1965. См.: Д. Цэнд. - //’Шинжлэх Ухааны Академийн мэдээ”. 1968. №4.

8. Готов Ц. Культура Монголии до народной революции /Современная Монголия. 1959, №8, С. 39-46

9. Готов Ц. Формирование монгольской национальной интеллигенции. Автореф. канд. дис. М, 1959.

10. Гунгаадаш Б. Монголия сегодня, М., 1969, С. 82

11. Давагсүрэн Ц. Достижение Монголии в культурном строительстве // Проблемы мира и социализма. 1965. №4 (80), С. 23-27

12. Давыдов Л. Ширится культурное строительство //Международная жизнь. 1969, №3. С. 109-110

13. Даревская Е. М. Сибирь и Монголия. Очерки русско-монгольских связей в конце IX - начале XX веков. Иркутск, 1994 
14. Древнемонголькие города. -М, 1965., К. В. Вяткина. Монголы Монгольской Народной Республики // Восточно-Азиатский этнографический сборник, “Труды Ин-та этнографии АН ССCР”, нов. Серия, Т. LX, M-Л., 1960

15. Жуковская Н. Л. Второй международный конгресс монголоведов, “Сов. Этнография", 1971

16. Жуковская Н. Л. Этнографические исследования в МНР //Советская этнография. 1972. №5.

17. Жуковская Н. Л. Ламаизм и ранние формы религии. М., 1977.

18. Задаев Б. С. Западная Монголия в трудах Российских исследователей и путешественников XYIII-начала XX вв. Автореферат дисс. на учёной степени канд. ист. наук. СПб, 2006

19. Златкин И. Я. Очерки новой и новейшей истории Монголии. М., 1957.

20. История Монгольской Народной Республики. М., 1954.

21. История Монгольской Народной Республики. М., 1967.

22. Кляшторный С. Г, Лившиц В. А. Согдийская надпись из Бугута, //Страны и народы Востока. Вып. Х, М., 1971

23. Козлов П. К. Монголия и Амдо и мертвый город Хара-хото. -М,-Пб., 1923.,

24. Козлов П. К. “Монголия и Кам. Трехлетнее путешествие по Монголии и Тибету. (1899-1901 гг.).-М, 1947.,

25. Козлов П. К. Дневники Монголо-Тибетской экспедиции. 1923-1926. /Отв.ред. А. В. Постников; Ред.-сост. Т. И. Юсупова; Сост. А. И. Андреев. СПб., 2003. Научное наследство. Т. 30.

26. Конституция и основные законодательные акты МНР”. М, 1952.

27. Культура Монголии в середние века и новое время (XYI - начало ХХв). Улан-Удэ, 1986

28. Ларичев В. Е., Азия далёкая и таинственная, Новосибирск, 1968 и другие работы.

29. Ларичев В. Е. Палеолит Северной, Центральной и Восточной Азии, ч. 1. Азия и проблема родины человека, Новосибирск, 1969

30. Лиштованный Е. И. “Востоковедение в Иркутске”, //Сов. Молодёж. 1983. 2 июля. ., "Исторические взаимоотношения Сибирии и Монголии: культура и общество (XIX в. 30-е гг. ХХв)”. Улан-Удэ. Изд-во БНЦ СО РАН, 1998.

31. Малакшанов К. Л. Советско-Монгольское культурное сотрудничество в период завершения строительства социализма в МНР // Труды Иркутского института народного хозяйства. Вып. 1. 1966. С. 203-220. 
32. Масленников В. А. Монгольская Народная Республика на пупти к социализму. М., 1951.

33. Машлай Т. Развитие общеобразовательной школы Монголии (1911-1940 гг). Автореф. канд. дис. М, 1965.

34. Майский И. М. Монголия накануне революции. - М, 1959.

35. Мендэ, Сарипсов А. К проблеме культурной революции в МНР. // Хозяйство Монголии. 1930. №5 (23) - 6 (24), С. 55-64.

36. Михайлов Г. И. Очерк истории современной монгольской литературы. М, 1955. См.: Т. А. Бурдукова. - //“Советское востоковедение”, 1957, №6. С. 142-143

37. Михайлов Г. И. Культурное строительство в МНР. Исторический очерк. М, 1957, Рец.: Г. К. Меклер.-//“Советское востоковедение”, 1958, №5. С. 189

38. Михайлов Г, Яцковская К. Монгольская литература. (Краткий очерк), М, 1969

39. Монголоведные исследования. Выпуск 1. Улан-Үдэ. 1996

40. Новоградова Э. А.. Мифы и культы древней Монголии.-Вестник Академии наук СССР. 1980, № 2., Мир петроглифов Монголии.-М, 1984.

41. Окладников А. П, Сэр-Оджав Н. 1960 онд явуулсан эртний судлалын шинжилгээний ажлын тухай. ШУАМ. 1961, №2.

42. Окладников А. П., Ларичев В. Е.. Археологические исследования в Монголии в 1967г., Известия Сибирского отделения (далее СО) АН ССР, 1968, №11, вып. 3, серия общественных наук; их же,

43. Окладников А. П, Деревянко А. П. Деревные культуры восточных районов в МНР, Сов. Археология, 1969, №4; их же, Тамцак-Булак-неолетическая жультура Восточной Монголии, Труды Бурятского института общественных наук Бурятского филиала СО АН СССР, Улан-Удэ, 1970, вып. 13, серия востоковедения;

44. Окладников А. П. Петроглифы Чулуутын-гола (Монголия).-Новосибирск, 1981.

45. О деятельности научных трудах О. М. Ковалевского. см.: Шамов Г.Ф. Научная деятельность О. М. Ковалевского в Казанском университете.-Очерки по истории русского востоковедения. М, 1956

46. Очерки истории культуры МНР. -Улан-Удэ, 1971. С. 11.

47. Позднеев А. М. Города Северной Монголии. СПб, 1880, Позднеев А. М. Монголия и монголы. Результат поездки в Монголию, исполненной в 1892-1893 гг. Т. 1. СПб, 1896.

48. Потанин Г. Н. Очерки северо-Западной Монголии. -Вып, 4. Материалы этнографические. СПб, 1883

49. Пржевальский Н. М. Монголия и страна тангутов. -М, 1946 
50. Роглан Л. Культурное строительство в Монгольской Народной Республике.//В кн.: Ответы на вопросы трудящихся. Сб. Вып. 62. М, 1966. С. 57-63.

51. Рона-Таш А. По следам кочевников. Монголия глазами этнографа, М., 1964.

52. Рязановский В. А. К водросу о влиянии монгольской культуры и монгольского права на русскую культуру и право. Харбин, 1931. С. 31.//Отд. Оттиск из “Изв. Юридич. Фак." Т. 9.

53. Сандаг Ш. Объективность или фальсификация (Открытое письмо господину Солсбори). -“Новости Монголии”, 1970, № 37, от 6 мая.

54. Сергеев В. А. Культурное строительство и рост материального благосостояния трудящихся Монгольской Народной Республики. //В кн.: “40 лет народной Монголии. М, 1961

55. Советское монголоведение., M, 1987

56. Такмаков Б. Культура и просвещение в Монголии. //Народное образование. 1949. № 11 .

57. Такмаков Б. Культура монгольских казахов. //Жулдыз. 1963, № 11, С. 135-140. (на казахском языке)

58. Устюжанинов И. Н. Культура монгольского народа.-В сб.: <<МНР>>. М., 1952

59. Писарев В. И. МНР на пути к завершению строительства социализма. М., 1964

60. Ц Цаплина Ф. С. Успехи культурного строительства.-В сб.: <<Монгольская народная Республика 1921-1961 гг >>, -М, 1961

61. Чимитдоржиев Ш.Б. Русско-Монгольские связи в области культуры и просвещения (нач. XX в) //Y международный конгресс монголоведов. Уланбатор, сент. 1987. Доклады советской делегации. -М., 1987. -Т. 1: История, экономика, - С. 170-179.

62. Ширэндыб Б. Современное состояние общественных наук в МНР, Народы Азии и Африки, 1964, №4. 